\title{
Tripogonella minima \\ (Poaceae: Chloridoideae: Cynodonteae: Tripogoninae), a new record for Asia from Peninsular India
}

\author{
J. Swamy \\ Botanical Survey of India, Deccan Regional Centre, Kendriya Sadan, GPOA, Sultan Bazar, Koti, \\ Hyderabad, Telangana - 500 095, India. \\ E-mail: swamy.2706@gmail.com
}

\begin{abstract}
Tripogonella minima (A.Rich.) P.M.Peterson \& Romasch. (Poaceae: Chloridoideae: Cynodonteae: Tripogoninae), a species indigenous to tropical Africa is reported here as an addition to the angiosperm flora of Asia from Telangana state, India. Detailed description, photographs and notes are provided for easy identification.
\end{abstract}

Key words: India, New record, Poaceae, Telangana.

\section{Introduction}

Tripogonella P.M.Peterson \& Romasch. is a newly established genus based on molecular studies of Tripogon Roem. \& Schult. and is distributed in tropical and subtropical America, Africa, Madagascar, New Guinea and Australia (Peterson et al., 2016). The genus is a member of subtribe Tripogoninae Stapf, tribe Cynodonteae Dumort., in subfamily Chloridoideae Kunth ex Beilschm. (Peterson et al., 2016; Soreng et al., 2017). Tripogonella is represented by only three species viz., Tripogonella loliiformis (F.Muell.) P.M.Peterson \& Romasch., Tripogonella minima (A.Rich.) P.M.Peterson \& Romasch., and Tripogonella spicata (Nees) P.M.Peterson \& Romasch. Tripogonella loliiformis is native from New Guinea to Australia, T. minima is found in tropical Africa, excluding the Congo basin, and

Received: 17.07.2020; Revised \& Accepted: 01.09.2020 Published Online: 30.09.2020 southwards to Natal, Cape Verde Islands and Madagascar (Phillips \& Launert, 1971), while Tripogonella spicata is distributed in North America, Central America, South America, and the Caribbean Islands.

While exploring the grasses of Telangana state, a small population of a Tripogonella species was observed in Medak district and a few specimens were collected from the existing population by the author. The voucher specimens were studied critically and identified as Tripogonella minima. The species is similar to Tripogon purpurascens Duthie by its habit and 2-lobed lemma with a midvein that extends into a small mucro and awnless lateral lobes but differs by its smaller habit, glabrous leaf-blades, number of florets, shorter racemes, length of spikelets, shape and size of glumes, length of lemmas, shape and size of paleas and length of anthers. A comparison of morphological characters of Tripogonella minima and Tripogon purpurascens is provided in Table 1. The identification is further confirmed by matching the specimens with electronic images of herbarium specimens at Kew Herbarium Catalogue (http://www.apps.kew.org). Hence, it is reported here as an addition to the flora of Asia. Detailed description, notes, and photographs are provided to facilitate its identification. Voucher specimens are deposited at Botanical Survey of India, Deccan Regional Centre (BSID), Hyderabad, Telangana. 


\section{Taxonomic treatment}

Tripogonella minima (A.Rich.) P.M.Peterson \& Romasch., Taxon 65(6): 1278. 2016. Festuca minima A.Rich., Tent. Fl. Abyss. 2: 436. 1850. Tripogon minimus (A.Rich.) Hochst. ex Steud., Syn. Pl. Glumac. 1: 301. 1854. Lectotype (designated by Peterson et al., 2016): ETHIOPIA, Prope Djeladjeranne in montibus versus fluvium Tacaze, 03.08.1840, G.W. Schimper 1652 (P [P00439486 digital image!]).

Fig. 1

Small caespitose perennials. Culms $2-5 \mathrm{~cm}$ tall, erect, slender, wiry, with 1 or 2 nodes; nodes c. 0.32 $\times 0.61 \mathrm{~mm}$, glabrous. Leaf sheaths mostly basal, 4$11.4 \mathrm{~mm}$ long, $0.2-0.47 \mathrm{~mm}$ wide, closely enclosing culms, glabrous, finely striate, involute along margins, persistent at the base, and becoming fibrous as they age; ligules $c .0 .13 \times 0.78 \mathrm{~mm}$, membranous with rim of hairs, hairs $c .0 .08 \mathrm{~mm}$ long; leaf-blades $c .5 .0$ $\mathrm{mm}$ long, c. $0.01 \mathrm{~mm}$ wide, flat to folded, filiform, 8-10-veined, very minutely scabrid along margin and upper surface, apex acute. Inflorescence a spikelike raceme with a single spikelet per node; peduncles 10-17 mm long, c. $0.37 \mathrm{~mm}$ wide, enclosed by upper leaf sheath; racemes 10-43 mm long, straight or slightly curved towards apex; spikelets alternate, distichous, linear to narrowly elliptic, sub-sessile to shortly pedicellate on a sinuous, c. $0.35 \mathrm{~mm}$ wide rachis, 3-6-flowered, laterally compressed, membranous, basal ones $1.93-2.69 \times 0.26-0.39 \mathrm{~mm}$, distal ones $2.54-3.47 \times$ $0.60-0.67 \mathrm{~mm}$, green tinged with purple; pedicels $c$. $0.2 \mathrm{~mm}$ long, spaces between the spikelets gradually decreasing from base to apex, c. $4.10 \mathrm{~mm}$ at the base and c. $1.35 \mathrm{~mm}$ at apex. Lower glumes oblonglanceolate, $1.30-1.81 \times 0.18-0.35 \mathrm{~mm}$, lobed above the middle on one side, acuminate at apex, 1-veined, scabrid on the midvein, thinly membranous. Upper glumes narrowly oblong, 1.78-1.95 × 0.23-0.31 $\mathrm{mm}$, apex acute to sub-obtuse, 1 -veined, scabrid on vein and at apex. Lemma elliptic, 1.28-1.32 × 0.32$0.36 \mathrm{~mm}$ (excluding awn), rounded on the back, 3-veined, lateral awns only slightly excurrent, stramineous on veins, apex emarginate with two small teeth, mucronate from the sinus, the mucro c. $0.8 \mathrm{~mm}$ long. Callus villous, densely bearded in front at the base of the rachilla internode; hairs 0.14$0.78 \mathrm{~mm}$ long, whitish. Paleas elliptic-lanceolate, $0.8-1.05 \times 0.20-0.25 \mathrm{~mm}$, shorter than lemma, apex acute, narrowly winged on the keels; keels minutely ciliolate along the margins. Lodicules minute, obcuneate, $c .0 .23 \times 0.20 \mathrm{~mm}$, apex truncate. Stamens 3; filaments, $0.26-0.30$ long; anthers $0.26-0.31 \times c$. $0.12 \mathrm{~mm}$, purplish-pink. Ovary ellipsoid, c. $0.23 \times$ $0.16 \mathrm{~mm}$; style $0.07 \mathrm{~mm}$ long; stigma $0.30-0.36 \mathrm{~mm}$ long, purplish-pink.

Flowering \& fruiting: Flowering and fruiting from May to July.

Habitat: The species is known from only one locality in Telangana (India) in open areas of dry deciduous forests. It grows in association with Chrysopogon fulvus (Spreng.) Chiov., Oropetium roxburghianum (Schult.) S.M.Phillips (both Poaceae) and Hyptis suaveolens (L.) Poit. (Lamiaceae).

Distribution: Indigenous to tropical Africa, excluding the Congo basin, and southwards to Natal; Cape Verde Islands and Madagascar (Phillips \& Launert, 1971), recently naturalised in India (Telangana).

Specimens examined: INDIA, Telangana, Medak district, Chegunta, N $17^{\circ} 58^{\prime} 13.6452^{\prime \prime}$ E $78^{\circ} 26^{\prime}$ 51.6372", 564 m, 28.06.2020, J. Swamy 009302 (BSID).

Notes: The species is similar to Tripogon purpurascens in its habit and 2-lobed lemma with the midvein extending in to a small mucro and the lateral lobes awnless, but differs in having shorter culms, glabrous leaf blades, number of florets, shorter racemes, length of spikelets, shape and size of glumes, length of lemmas, shape and size of paleas and length of anthers.

\section{Acknowledgements}

The author is thankful to Director, Botanical Survey of India, Kolkata and Dr. P.V. Prasanna, Officer 


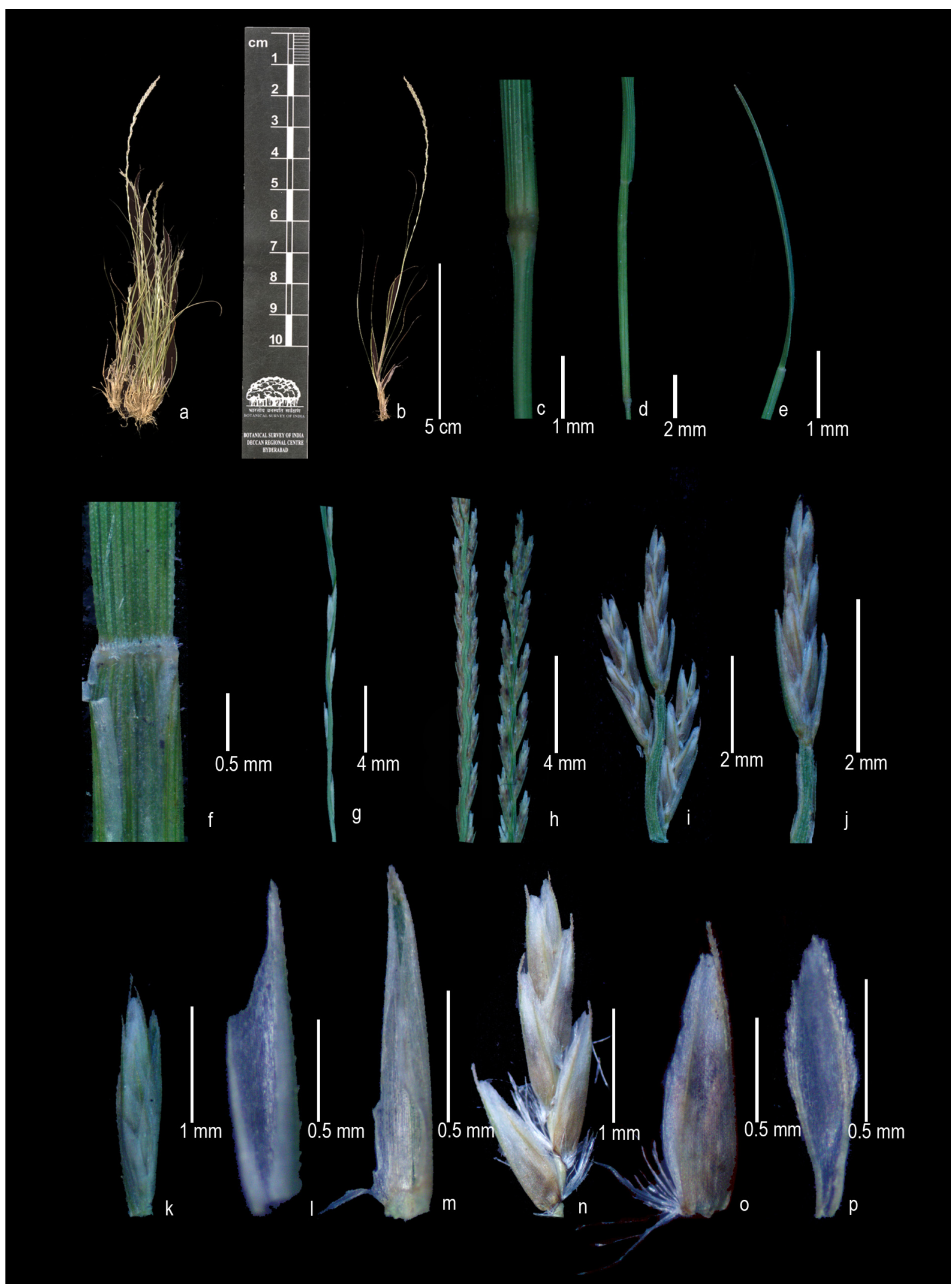

Fig. 1. Tripogonella minima (A.Rich.) P.M.Peterson \& Romasch. a. Habit; b. Culm with inflorescence; c. Node; d. Leaf sheath; e. Leaf blade; f. Ligule; g. Lower portion of raceme; h. Middle to upper portion of racemes; i. Spikelets; j. Terminal spikelet; k. Lower spikelet; I. Lower glume; m. Upper glume; n. Florets; 0. Lemma; p. Palea (all from J. Swamy 009302; Photos by J. Swamy). 
Table 1. Morphological comparison of Tripogon purpurascens and Tripogonella minima

\begin{tabular}{|l|l|l|}
\hline Characters & Tripogon purpurascens Duthie & $\begin{array}{l}\text { Tripogonella minima (A.Rich.) P.M.Peterson } \\
\text { \& Romasch. }\end{array}$ \\
\hline Culms & $4-18 \mathrm{~cm}$ tall & $2-5 \mathrm{~cm}$ tall \\
\hline Leaf-blades & Densely pilose adaxially and glabrous abaxially & $\begin{array}{l}\text { Very minutely scabrid adaxially } \\
\text { and glabrous abaxially }\end{array}$ \\
\hline Racemes & $30-150 \mathrm{~mm}$ long & $10-43 \mathrm{~mm}$ long \\
\hline Peduncles & $70-110 \mathrm{~mm}$ long & $10-17 \mathrm{~mm}$ long \\
\hline Spikelets & $2.5-7 \mathrm{~mm}$ long & $1.93-3.47 \mathrm{~mm}$ long \\
\hline Lower glumes & $1.5-3 \mathrm{~mm}$ long, acute at apex & $1.30-1.81 \mathrm{~mm}$ long, acuminate at apex \\
\hline Upper glumes & Elliptic to lanceolate, $(2-) 2.6-4.5 \mathrm{~mm}$ long & Narrowly oblong, 1.78-1.95 mm long \\
\hline Florets in a spikelet & 2 (rarely 3) & $3-6$ \\
\hline Lemmas & $2-4.5 \mathrm{~mm}$ long & $1.28-1.32 \mathrm{~mm}$ long \\
\hline Paleas & Obovate to elliptic, 2-4 mm long & Elliptic to lanceolate, $0.8-1.05 \mathrm{~mm}$ long \\
\hline Anthers & $1-1.2 \mathrm{~mm}$ long & $0.26-0.31 \mathrm{~mm}$ long \\
\hline
\end{tabular}

In-charge, Botanical Survey of India, Deccan Regional Centre, Hyderabad for facilities and to the officials of Telangana State Forest Department for permission.

\section{Literature Cited}

PETERSON P.M., ROMASCHENKO K. \& Y. HERRERA ARRIETA 2016. A molecular phylogeny and classification of the Cynodonteae (Poaceae: Chloridoideae) with four new genera: Orthacanthus, Triplasiella, Tripogonella, and Zaqiqah; three new subtribes: Dactylocteniinae, Orininae, and Zaqiqahinae; and a subgeneric classification of Distichlis. Taxon 65(6): 1263-1287. http://doi.org/10.12705/656.4

PHILLIPS S.M. \& E. LAUNERT 1971. A revision of the African species of Tripogon Roem. \& Schult. Kew Bulletin 25(2): 301-322.

SORENG R.J., PETERSON P.M., ROMASCHENKO K., DAVIDSE G., TEISHER J.K., CLARK L.G., BARBERÁ P., GILLESPIE L.J. \& F.O. ZULOAGA 2017. A worldwide phylogenetic classification of the Poaceae (Gramineae) II: An update and a comparison of two 2015 classifications. Journal of Systematics and Evolution 55(4): 259-290. https://doi.org/10.1111/ jse. 12262 